InOedia $\quad \begin{aligned} & \text { InMedia } \\ & \text { The French Journal of Media Studies }\end{aligned}$

$4 \mid 2013$

Exploring War Memories in American Documentaries

\title{
Audio-Visual: Disembodied Voices in Theory
}

Anaïs Le Fèvre-Berthelot

\section{(2) OpenEdition}

\section{Journals}

Electronic version

URL: http://journals.openedition.org/inmedia/697

ISSN: 2259-4728

Publisher

Center for Research on the English-Speaking World (CREW)

Electronic reference

Anaïs Le Fèvre-Berthelot, " Audio-Visual: Disembodied Voices in Theory », InMedia [Online], 4 | 2013,

Online since 21 November 2013, connection on 07 September 2020. URL : http://

journals.openedition.org/inmedia/697

This text was automatically generated on 7 September 2020

(c) InMedia 


\title{
Audio-Visual: Disembodied Voices in Theory
}

\author{
Anaïs Le Fèvre-Berthelot
}

1 The debates around film sound coincide with ontological discussions about the cinematic medium. The issue of the voice-over in this context is particularly telling as speech has often been seen as a threat to the purity of film. Yet, cinema has never been silent and, from the medium's very inception, sound was always supposed to go along with moving images; ${ }^{1}$ and while synchronized film sound generalized almost ninety years ago, television has always been an audio-visual medium, where the voice plays a crucial part.

2 Compared with the flow of contributions centering on the image, the silence of academics on sound in audio-visual media was at times deafening. This visual emphasis of cinema studies may be the product of a visual bias in western culture. The primacy of the image in audiovisual media may also stem from the elusiveness of sound as an object. Tools are seemingly lacking for aspects of film sounds other than music, if only to describe sound itself. By nature hard to render in words (in everyday life, we frequently rely on visual or tactile metaphors to describe a sound), sound is usually considered for what it signifies or stands for rather than for itself. Another complication to the study of film sound, its history and its reception arises from the transient quality of sound, and from the lack of adequate tools for discussing the variety of audiences' experience. By focusing on the treatment of a specific type of film sound -the disembodied voice- this essay sets out to determine how theorists have tried to overcome such obstacles, allowing traditional frontiers to shift between image, sound, and spectator in audiovisual media.

3 The topic of film sound is of course too vast to conduct an exhaustive review. The scope of this essay will be restricted to the asynchronous voice in fictional audiovisual production. ${ }^{2}$ The numerous studies on the transition from silent to sound film as well as the specific production linked to film music will therefore not be included in this review. ${ }^{3}$ The evolution of analyses of the disembodied voice is quite representative of the larger trends of the field. It underlines the issues at stake in the debates that 
surround the terminology of film sounds (should we speak of a "voice-over," a "voiceoff," an "acousmatic voice," or a "narrating voice"?). In addition, such analyses provide a good example of the difficulty in pinpointing the location of a sound (what is "in" and what is "off"?), and also throw light on the sound-image and sound-spectator relationships (how/from where is this voice heard?).

The field of film sound studies was built on the basis of discussions that followed the generalization of synchronized film sound in the 1930s. A brief overview of these debates is necessary to better situate and understand the subsequent approaches of the disembodied voice. Following this theoretical introduction, we will be able to distinguish three perspectives that have marked the approach of the asynchronous voice in audiovisual media and should be analyzed more precisely. Borrowing from semiology and narratology, an essentially descriptive approach first appears that raises issues of taxonomy. Heavily influenced by Lacanian theories and their later adaptations by feminist film theorists, a second approach emerges that introduces the figure of the subject and emphasizes the possible meanings of the disembodied voice. These approaches focus on sound and voice for what they signify rather than as signifiers. This limitation can be overcome by semio-pragmatic or cognitive approaches that take into account the experiences of audiences in their diversity. While most studies of sound in audio-visual media have concerned film, this final part will give us the opportunity to consider the specificity of the televisual medium and the way it has been tackled by some theorists.

\section{Previously in Film Sound Studies}

5 Classical sound theory was built on the premise that cinema was essentially a visual medium. Early critics therefore considered sound with skepticism when synchronized sound was introduced and generalized in the late 1920s. This original discussion of film sound informed the debate for almost fifty years. Opponents of film sound generally did not refuse sound as a whole, but thought that the introduction of speech threatened the purity of cinematic language. This original bias led directors and theorists to denounce synchronous speech as something that was at best redundant, and that at worst corrupted the purity of the image. ${ }^{4}$ Theoretician-directors such as René Clair ${ }^{5}$ or the Soviet directors Eisenstein, Pudovkin and Alexandrov ${ }^{6}$ thus expressed their hostility towards the intrusion of synchronous speech in cinema. Some advocated a contrapuntal or asynchronous use of sound to preserve the power of the image. The fear that, with sound, cinema would be assimilated to filmed theater was also expressed by critics such as Rudolf Arnheim, who wrote in 1938 a severe criticism of talkies in "A New Laocoön: Artistic Composites and the Talking Films". In this essay, he regrets the "impressive decline of artistic excellence" linked to the growing presence of "visually poor scenes full of dialogue."

6 When synchronized sound became an inescapable dimension of films, the debate moved from the definition of cinema as a visual medium to the defense of realist aesthetics. Although they viewed sound more positively as a potential source of added realism, later critics still fell victim to what Rick Altman calls the "ontological fallacy," whereby cinema is essentially considered as a visual medium "and the images must be/ are the primary carriers of the film's meaning and structure." ${ }^{8}$ Traditional hierarchies favoring the image were still very strong in the first writings that took sound into 
account. Siegfried Kracauer's chapter on "Dialogue and Sound" in his Theory of Film is thus an attempt at a theory of sound that posits sounds as part of material reality and, therefore, as intrinsically cinematic. However, by giving primacy to cinema's visual nature, Kracauer fails to subvert traditional hierarchies: "For sound films to be true to the basic aesthetic principle, their significant communications must originate with their pictures." In the same train of thought, the idea of sound as a source of added realism in cinema is also expressed by Jean-Louis Baudry in his essay, "Le Dispositif," on the cinematic apparatus. Drawing a parallel between cinema and Plato's cave, Baudry reduces sound to an element that helps make the "artifice as resembling as possible." ${ }^{10}$ Written in the 1970s, this article shows the persistence of essentialist approaches of the medium.

7 Despite their shortcomings, such reconsiderations of film sound led to efforts to establish taxonomies describing the audio phenomenon. In 1935, Raymond Spottiswoode in his Grammar of the Film classified film sound into three categories "natural sound," "speech" and "music," and suggested that sounds be categorized according to their position on two scales: the "realistic-non-realistic" and the "parallel -contrastive." ${ }^{11} \mathrm{He}$ also defined different types of uses for each sound: realistic, selective, commentative, tonal, etc. Likewise, in 1946, Pierre Schaeffer, a French composer, filmmaker and theoretician, wrote a series of short articles on the nonvisual element of cinema classifying film sound into three normative categories, from most to least realistic: noise, speech and music. ${ }^{12}$ Although such classifications were anchored in industrial practice as they coincide with the way the film soundtrack was mixed, ${ }^{13}$ the main criterion for categorization remained realism, which led to prescriptive conclusions about the use of sound and speech in films. Schaeffer eventually claims, like Kracauer and Baudry, that speech should be nothing but "an echo of reality." ${ }^{14}$ In the end, this vocabulary, which still forms the basis for discussion today, is grounded in the supposedly unequal relation between sound and image. As a result, even though these seminal writings are landmark contributions to the field, their relevance is also somewhat limited by their authors' normative perspective, which distinguishes between good and bad sound practices.

8 Ontological considerations about cinema progressively gave way to analyses of sound for and in itself. Technological innovations such as the Dolby system ${ }^{15}$ led to a surge of interest from the mid-1970s onwards and oriented critics towards an approach that took into account the physical, historical and semiological aspects of film sound. ${ }^{16}$ In a series of four seminal articles published in Les Cahiers du Cinéma, ${ }^{17}$ Claude Bailblé delineates issues that proved central in the following years, such as the role of technology, the centrality of voice, the history of film sound, etc. American and French scholars quickly followed Bailblé's trail with the publication of the sixtieth issue of Yale French Studies ${ }^{18}$ on cinema sound. Presented by the editor Rick Altman as a "remedial" publication, this special issue sought to encourage academics to write more about sound. In this issue, the articles bring together historical and theoretical perspectives, from feminism and psychoanalysis to semiotics. This variety of approaches shows that sound had become a real object of study.

9 As illustrated by his concept of "audio-vision", Michel Chion, the French composer, filmmaker, critic, teacher and scholar, aims to go beyond traditional hierarchies. In his various books published on the topic from 1982 onwards, Chion debates over the (in)equality of sound and images. His work underlines the specificity of film sound in 
relation to the film as a whole. He thus focuses on the combination of sound with other cinematic elements. The notion of "audio-vision" points to a perceptive practice induced by audiovisual media ${ }^{19}$ - that is, in Chion's own words:

the type of perception proper to the experience of film and television (...) wherein the image is the conscious focus of attention, but one to which the sound supplies at every moment a series of effects, sensations, and meanings. ${ }^{20}$

Chion's argument that sight and hearing are not divisible eventually points to sound perception as a social construct.

The social nature of sound perception was taken into account by Rick Altman among others, notably in the reader he edited twelve years after the Cinema/Sound issue of Yale French Studies. Altman's Sound Theory, Sound Practice ${ }^{21}$ was one of the major anthologies on the topic of film sound. ${ }^{22}$ The evolution of sound studies can be measured by comparing the contents of both publications edited by Rick Altman. The film sound specialist regrets that in Cinema/Sound "the sounds of silent films are hardly mentioned; sound technology is almost entirely neglected; no attention is paid to nonnarrative, non-feature, or non-western films." ${ }^{23}$ By contrast, in the 1992 anthology, Altman embraced a different approach, this time taking into account the context of production and reception of a film. To this end, the film is no longer to be considered as a text but as an event. This fruitful perspective allows the contributors to tackle issues of instability, materiality, multi-discursivity or mediation in relation to film sound. Altman has many followers including Jay Beck and Tony Grajeda who edited in 2009 a collection of essays on critical studies in film sound and underline that "part of our work as sound scholars entails locating these seemingly 'natural' relationships and exposing how they have been artificially constructed." ${ }^{24}$

\section{From the Text to the Audience: Issues of Taxonomy}

11 The variety of approaches of film sound outlined above is echoed in the works of critics that revolve around the problematic status of the voice. Because it is so closely linked to speech, the voice-over has suffered from similarly negative reviews based on the same ontological fallacy: why tell what you can show? ${ }^{25}$ The first difficulty one encounters when wanting to talk about film sound is the lack of an adequate lexicon. The various attempts at a classification of film voice usually revolve around the vocabulary of narratology ("diegetic" and its multiple variations: homo-, extra-, meta-,etc.) and around the in/off/over triad. As a result of the interest for the location of the source of sound, naming the voice when it is not attached to a source visible on screen has become a key issue and a scholar writing on the topic cannot but justify the terms he or she has selected, as the lexicon inscribes the author within a particular tradition. ${ }^{26}$

12 In an article published in the 1973 issue of Ça/Cinéma, Daniel Percheron, provides a taxonomy in line with those offered by Kracauer, Spottiswoode or Schaeffer, as he tries to "differentiate between the iconic and diegetic functions of the sound-track, as well as to distinguish between music, words, and sound effects." ${ }^{27}$ Percheron focuses on the "on/off" distinction as the basis for a more specific categorization. To illustrate this distinction, he isolates four types of "off" voice-over (interior monologue, unmarked "off" voice-over, voice-over on flashback, and commentary) which can be "specified by their relationships to 1) the diegesis; 2) synchronization with the image track; and 3) 
the mode of communication" ${ }^{28}$ Expanding on such categories, Percheron re-integrates all cinematic sounds into a synthetic diagram that underlines the complexity of off sound. Percheron's model sustains a textual approach of the film, as he produces a hierarchy of film sounds concluding that "only the spoken word can constitute a highly significant system." ${ }^{29}$

Still in a textual perspective, Sarah Kozloff, a film professor at Vassar, wrote a short book entitled Voice-Over Narration in American Fiction Film..$^{30} \mathrm{After}$ opening her book on a defense of voice-over and a history of this device, Kozloff uses narratological and semiological tools borrowed from Genette and Metz to investigate the narrative function of first and third-person narrating voice-overs. She thus defines four types of narrators depending on whether they are "framing" or "embedded" and "heterodiegetic" or "homodiegetic". Kozloff's primary concern is to determine who is speaking, from where and to say what. She insists that those different types of narrators are "always embedded within the image-maker's discourse." ${ }^{11}$ The paradox of the relationship between the voice-over narrator and the image-maker from the spectators' point of view provides fruitful leads for further research on the topic, as Kozloff does not elaborate on this question. Despite its sometimes excessively textual approach of the medium, which tends to erase the physical dimension of the voice, the author suggests new, compelling perspectives of study such as a historical or a gender approach of voice-over. Textual approaches such as these stem from the desire to rehabilitate speech in cinema, but would benefit from a more diverse vocabulary that allows to consider film sounds as events.

Despite the influence of narratology in film studies, film sound studies really emerged as a discipline at a time when psychoanalytic and feminist theories were a major influence in film studies. Thus the field was influenced by those theories in the 1970s and 1980s. In La Voix au cinéma, ${ }^{32}$ published in 1982, Chion draws heavily from Lacanian theories, assimilating voice in cinema with a fetish and insisting on the power of voice. According to Chion, the voice that comes from nowhere takes us back to the early stage of life in utero. This analysis of the disembodied voice led Chion to theorize the "acousmaton," ${ }^{33}$ this "sensory phantom constituted by a sound whose source is invisible." ${ }^{34}$ Omnipotent and omniscient, the acousmaton, or acousmatic being, derives its power from the voice's relation to something primal. Many writers on film sound attribute power to the disembodied voice. ${ }^{35}$ This is, however, a presumption that deserves closer examination and should not be taken for granted.

Influenced by psychoanalytic approaches, feminist theorists Mary Ann Doane and Kaja Silverman embraced this presumption and strove to delineate precisely different types of voice in cinema. In "The Voice in Cinema: The Articulation of Body and Space," Doane relies on the criterion of space to distinguish between synchronous voice, voiceoff (i.e. the character is outside the frame), interior monologue, voice-over in a flashback, and disembodied voice-over. ${ }^{36}$ In "Dis-Embodying the Female Voice," Silverman's categorization is built around the notion of "embodiment," her point being that the female voice is always brought back to the female body (contrary to the male voice-over, which is more often detached from the body). ${ }^{37}$ This notion produces a taxonomy similar to that elaborated by Doane. The association implied by these authors of synchronous speech with feminization (and therefore disempowerment) through embodiment, as a result of patriarchal ideology, quickly shows its limits. The example of the female voice-over in Joseph Mankiewicz's A Letter to Three Wives is thus 
dismissed by Silverman as an exception she does not bother to account for.$^{38}$ The search for a taxonomy tending to cover all possible combinations may have led critics to lose sight of the specificity of each occurrence. The strict definition of each type of voice/ image combination becomes even more problematic when, to each combination, a meaning is applied with no consideration for the general context.

In other works, critics seem more aware of this risk and offer vocabularies that take into account the heterogeneity of the voices and the various effects they may have. Chion was one of the first to underline that even though film sound must be analyzed in relation to the images, a merely additive approach is not convincing. The notion of "audio-vision" describes the mutual influence of sound and image in the production of a new entity. In all his works on sound, Chion's avowed aim has been to delineate the frontiers of the "study of heard sound." The bilingual glossary he put online in 2012 sums up more than thirty years of research on the topic of sound. This text shows Chion's systematic endeavor to create a specific taxonomy to "think and talk about film sound." ${ }^{39}$ Yet, it also underlines the difficulty of creating a vocabulary specific to film sound. Michel Chion's list of terms is long and full of neologisms that are not always easy to work with. Film scholars, when they refer to Chion, use only a small selection of his concepts. Alongside the "acousmaton," the "tricircle" is one such concept. First introduced in Le Son au cinéma, ${ }^{40}$ the tricircle is a model for analyzing the status of sound in relation to the images. Chion calls this typology the "tricircle" as it can be modeled as a circle divided into three equal parts representing three zones: offscreen, off, and in. In the tricircle, the separations are as important as the zones, since they emphasize the necessity to think about the passage from one zone to another. This model has the advantage of emphasizing the permeability of film sound events, such categories being usually more efficient when they are flexible. Alain Boillat mentions the tricircle model in his study of the voice-over, in which he also insists on the continuum of functions that can be attributed to the voice. ${ }^{41}$

This instability and ever shifting status of film sound categories are essential. For this reason, Britta Sjogren chose in her book on the female voice in film to use the term "voice-off." ${ }^{42}$ Her choice is influenced in part by the time she spent in France, but also by her desire to build an "analytic framework that allows for the unforeseen and for the contradictory exceptions enunciation produces." ${ }^{43}$ The choice of an unstable term is in keeping with Sjogren's project, namely to underline the paradox of the use of the female voice in cinema as a differentiating device.

It is the very mutability of the voice-off that characterizes it-the way it slips free of the image, glides in and out of its attachments to its apparent body, moving from (in Doane and Silverman's terms) voice-over to voice-off to embodied voice-over to badly synched sound and back again. ${ }^{44}$

Such flexible classifications tend to better take into account the spectators' perception of film sound. Chion thus writes that the division of sound into three (flexible) types is "implicit and intuitive even for the non-theoretician spectator." 45

In his textbook on the analysis of film sequences, Laurent Jullier goes further in the focus on the point of audition of the spectators. He defines the voice-off as the voice of "speakers" or "lecturers" who speak from somewhere off-screen that does not belong to the diegesis. ${ }^{46}$ Jullier classifies these voices according to the way they address the spectators. His classification insists on the implied position attributed to the spectators, who can be positioned for instance as investigators, students, or confidante, depending 
on the way the speaker addresses them. Jullier then proceeds to determine eight functions of the voice that are among the most common in films. The voice can thus be phatic, conative, explicative, metanarrative, testimonial, evaluative, designative, or have a performative function (Jullier calls it the "genie function") as in Mankiewicz's All About Eve (1950), when Addison De Witt has the power to freeze the image. Jullier's categorization is in keeping with his approach of film through reception and with his emphasis on spectatorship. The various approaches of film sound since the 1970s have contributed to the evolution of the field, from normative classifications concerned with the purity of the cinematic medium and considering mostly the sound-image relationship in a realist perspective to more flexible taxonomies that try to take into account the variety of sound events and the specificity of the audience's experience. Film sound and film voice have thus come to be acknowledged as complex phenomena in their own right.

\section{Through the Acoustic Mirror and What Was Found There}

The influence of psychoanalytic and feminist theories has been central in the development of film sound studies in the 1970s and 1980s. ${ }^{47}$ In his articles on film sound published in Les Cahiers du Cinéma, Claude Bailblé insists on the role of the voice in the birth of the subject. ${ }^{48}$ Michel Chion also underlines Lacan's central role in creating the voice as an object of study. ${ }^{49}$ Angelo Restivo explains this centrality of the voice in Lacanian theory by saying that the voice is to be conceived as "correlative to the gaze; it is that which 'sticks in the throat' in relation to the signification of meaning." ${ }^{50}$

Through the work of psychoanalysts like Guy Rosolato ${ }^{51}$ and Denis Vasse ${ }^{52}$ the voice has thus become the focus of some approaches of film sound. Both Rosolato and Vasse insist on the voice being related to the Mother and to a pre-Oedipal union. This perspective underlies Chion's analysis of the acousmaton and his definition of the voice as a link, an extension of the umbilical cord. Lacanian theories also underlie Chion's treatment of the female voice which he defines as an absolute as he writes: "The male scream outlines a territory, the female scream refers to the infinite, it swallows everything in itself, it is centripetal and fascinating, while the male scream is centrifugal and structuring. ${ }^{\prime 3}$ About the evolution of psychoanalytic sound theory in the 1990s, Angelo Restivo writes that it can be summarized in one sentence: "Michel Chion interpreted by Slavoj Zizek." ${ }^{54}$ By that, he means that Zizek appropriated a few of Chion's terms, and notably the acousmaton, to ground them in Lacanian theory. According to Restivo, psychoanalytic film sound studies now combine close attention to formal details with ideological analyses.

In La Voix au cinéma, Michel Chion explains the surge of interest for the voice by the feminist focus on an object considered more fluid and less strict (and therefore less masculine) than writing. The voice was a territory of freedom women had to conquer. The interest of feminist critics for the notion of the fetish is most famously represented by Laura Mulvey's essay on "Visual Pleasure and Narrative Cinema." ${ }^{55}$ Most emblematic of a second generation of feminist film critics that tried to revise Laura Mulvey's original model are Mary Ann Doane and Kaja Silverman whose books both tackle the role of the voice-over in classical cinema. Voice-over constitutes a productive area of investigation because of its equivocal status between fiction and the spectator's world. 
Traditionally associated with femininity, voice can be used in film as a mark of authority. Feminist writers thus try to come to terms with the paradox of the female voice-over. Mary Ann Doane is the author of several articles on the topic of film sound ${ }^{56}$ and writes about the voice-over in The Desire to Desire, her book on the woman's film. ${ }^{57}$ Doane explains that she takes psychoanalytical scenarios as models, "but they are models only insofar as they are symptomatic of a more generalizable cultural repression of the feminine." ${ }^{\text {8 }}$ Although Doane regrets that feminist theory "frequently and overhastily collapses the opposition between social and psychical subjects, closing the gap prematurely," 59 later feminist critics also failed to remedy this problem. In 1988, Kaja Silverman wrote The Acoustic Mirror: The Female Voice in Psychoanalysis and Cinema ${ }^{60}$ yet another work of reference on the issue. The expression "acoustic mirror" was coined by Guy Rosolato and taken up by Silverman to comprehend "a range of 'subjective' issues, from castration, projection, disavowal, and fantasy to narcissism, melancholia, and the negative Oedipus complex." ${ }^{61}$ Both Doane and Silverman insist on the link between the voice and the body, asserting that classical films "hold the female voice and body insistently to the interior of the diegesis, while relegating the male subject to a position of apparent discursive exteriority by identifying him with mastering speech, vision, or hearing." ${ }^{22}$ In this perspective, the female voice-over becomes a paradox that is solved by systematizing the symptoms of patriarchy. Although Silverman criticizes Chion's approach of the gendered voice as adopting "much of the symptomatic value of a Hollywood film"63 she would later find herself reproached with the very same flaw, notably by Rick Altman and Britta Sjogren. ${ }^{64}$

Rick Altman denounces those approaches as pertaining to the ontological fallacy formerly reserved to enemies of film sound..$^{65} \mathrm{He}$ criticizes the psychoanalytic approach to the voice in cinema as a "transhistoric proposal" and regrets that "an apparently ontological claim about the role of sound has been allowed to take precedence over actual analysis of sound's functioning." ${ }^{66}$ To some extent, Britta Sjogren fulfills Altman's wish for "historically grounded claims and close analyses of particular films rather than ontological speculations that presume to cover all possible practices." ${ }^{67}$ She studies the voice-off as "a marker of difference, an undeniable asset that marks the creative flex of contradiction that runs through the group of films examined [...]." ${ }_{68}$ Although Sjogren relies on psychoanalysis to some extent, she tries to go beyond what can be seen as its hierarchical approach to gender and to the medium. By re-reading Vasse and Rosolato, Sjogren confronts Doane and Silverman's pessimistic conclusion on the representation of women in cinema. According to Sjogren, because she focuses on demonstrating how the female subject is contained in films, Silverman deprives herself from the possibility of seeing a female subject. Silverman reproduces Chion's bias by associating the feminine with the body and the image, while subjectivity is necessarily masculine. Sjogren also criticizes Chion for offering no theory "as to how this voice-off [the female voice-off used to represent oblivion] may function relative to the spectator." ${ }^{69}$

24 Anchoring her feminist analysis of women's voices in classical Hollywood cinema in the history of the technologies of sound reproduction, Amy Lawrence had, before Sjogren, developped a slightly different approach of the female voice in cinema. ${ }^{70}$ She sees in the ideology of sound reproduction a bias against the female voice that bore consequence for sound film. Lawrence thus dissects three obstacles opposed to the presence of women's voices: "the myth of woman's 'naturally' less powerful voice, technical deficiencies, and [...] 'cultural distaste' for women's voice." Each of these "problems" 
is "a tangle of technological and economic exigencies, [...] suffused with ideological assumptions about woman's 'place."'72 Even though Lawrence still relies on feminist psychoanalytic approaches in her analyses of sequences, her thoughts on the mutual influence of technology and ideology relying on archives make her demonstration about the specificity of the female voice more convincing than Silverman's work.

Theories about the potential meanings of the voice-over in film show their limits when they are not paired with contextual analyses. Too often in these theories, the voice is considered as text and its physical and historical dimensions are overlooked. The other limit faced by these approaches is their notion of the spectator as a unique ahistorical entity. Flexible categories that take the variety of sound events and the diversity of the audiences' experiences into account therefore appear to be more productive.

\section{Hearing Voices}

Some critics have thus chosen to focus on the spectators' experience of sound in relation with production, images, and cultural context. This approach has led to historical research on the evolution of recording technologies or the ancestors of the voice-over. Taking the spectators into account also allows one to focus on reception conditions as well as practices pertaining to film sound and to the voice. To consider the various factors at stake in the production and reception of film sound, it is necessary to combine approaches and methodologies. Rick Altman thus states:

When we understood cinema as text, we borrowed our terminology and our methodology from previously established textual domains. An understanding of cinema as event requires new terms and models for a new type of multidimensional analysis. ${ }^{73}$

Altman defends an approach to cinema and film sound that considers "cinema events as the intersection of many separate lines of endeavor, throughout the production, reception, and cultural spheres." ${ }^{74}$ In this perspective, the diversity of the spectators must be taken into account, and the specific psychoanalytic explanation of the spectator's desire is not satisfactory. Focusing on film sounds is also a way not to forget that film is "always the product of a performance." 75 Rick Altman has paved the way to different analyses of film sound that link theory, aesthetics and history.

In one of the few monographs on the voice-over in cinema, Jean Châteauvert adopts a semio-pragmatic perspective ${ }^{76}$ to define the voice-over narrator and identify the elements that weigh on our perception of this voice. ${ }^{77}$ In his study, Châteauvert applies a new narratological model to cinema. He mentions the "listening instruction" implied by the spectators' desire to see the film. Indeed, Chateauvert sees the narrative structure as a device to direct our understanding of the film -one that, he insists, would not work without the spectator's personal encyclopedia of references necessary to make sense out of a sound. The dynamic relation between the contents of the film and the conditions of reception is essential to a semio-pragmatic approach.

Alain Boillat expands on the historical approach first sketched out by Châteauvert and Sarah Kozloff, as well as relies on Altman's work in his important research on the history of the voice-over. In Du bonimenteur à la voix-over, he analyzes early practices of orality, storytelling and commentary linked to images. ${ }^{78}$ Throughout his book, he is conscious of the necessity to consider the specificity of recorded film sound. Thanks to the definition of a continuum going from "attraction-voice" to "narration-voice" (from 
the voice that catches our attention to the voice that tells a story), the author opens new perspectives on the relations between audio and visual phenomena, thus discussing key notions in film studies. Although Boillat's discourse focuses on cinema, his conclusion mentions the new uses of the voice-over and outlines potential areas that could be studied thanks to his theoretical framework. He thus states that:

dubbing, post-synchronization of animated films and voice-mail belong to the action-voice model, while radio hosting, and advertising correspond to the attraction-voice model, mainstream films and video-games resort to narrationvoice, while other productions (trailers, websites, etc.) are somewhere in between the latter two. ${ }^{79}$

In a pragmatic perspective, François Jost briefly outlined three ways to study television sound in its own right..$^{80}$ The first is theoretical and implies analyzing the audience's new skills as well as the way sounds work across various TV genres. The second approach is historical and aims at showing the shift from intermediality to intergenericity. Finally, the third perspective is aesthetic and seeks to determine how television sounds, speech, and music are paired with images. These three approaches aim at comprehending the way television sound flux requires specific enunciative and cognitive skills from the audience. In a brief analysis of American television series as symptoms of our societies, Jost describes the use of the voice-over device in recent popular series as the result of the growing importance of intimacy. ${ }^{81}$ Although the size of this latter book prevented the author from following the paths outlined above, the study of the voice-over in television series would certainly benefit from the perspectives sketched out by Jost.

Laurent Jullier is the main representative of French film researchers adopting a cognitivist perspective that could correspond to the first path described by Jost. Jullier's approach combines different tools and goes further than Châteauvert in his analysis of reading processes implied by filmic and televisual narratives. Although his book, Les Sons au cinéma et à la télévision: précis d'analyse de la bande-son, treats television and cinema somewhat interchangeably, one difference he does point out is that in television a-filmic sounds are more common and lead to a blending of the three cinematic spaces (on, off, over) ${ }^{82} \mathrm{~A}$ few years later, Jullier developed this analysis in a paper on speech and sound in television from a cognitivist perspective..$^{83}$ In this paper, Jullier distinguishes between two modes of television spectatorship: being "in front" (television comes across as a mere "screen" whose contents do not engage the viewer's attention fully); and being "inside" (television appears as a "window" whose contents engage the viewer's attention and allow for identification or even interaction). Jullier relies on cognitive psychology to study the auditory position of the spectator in the TVas-window model. He shows that some categories used for the analysis of cinema sound are not as productive when applied to television: it is the case, for instance, of the oppositions between on and off or diegetic and extra-diegetic. Jullier also details the technological specificities of TV sound, which is generally smoother and conceals spatiality to erase the off-space. Thus, the way voices are recorded and mixed on television encourages vertical causality (the illusion that sound and image, because they are synchronous, have a causal relationship). Finally, while television voices do have power (owing to their combination of two models, that of the storytelling mother and the lecturer), Jullier insists that this power should not be overestimated. The power of the voices, he explains, stems essentially from the power of language. 
31 These new perspectives underline the evolution of the study of sound in audiovisual media since the generalization of synchronized film sound. The rise of audiovisual media other than film and television, and the generalization of the use of the voice by such media reinforce the need for theoretical tools that apprehend the audiophenomenon in relation with the contexts of production and reception.

In writings about film sound, it has been customary to lament the absence of research on the subject. However, this bibliographical overview of the discussions over voice in cinema shows that there is a growing and diverse literature on the subject. The focus on the asynchronous voice allows to touch on the various debates about taxonomy and theoretical perspectives that have stirred the academic community. From the generalization of synchronized sound to the advent of a new century marked by the emergence of new audiovisual phenomena, critics have followed a movement from film as text to audience reception.

First, film critics tried to assess the contribution of sound to film. After the first denunciations of synchronous speech as a redundant tool that threatened the purity of the medium, theorists tried to define sound in relation with the images. Although they usually preserved a hierarchy that favored the visual, their first attempts at a taxonomy pointed to film sound as a possible object of research. When film sound studies really developed from the late 1970s onwards, the first issue was with developing an appropriate vocabulary. The English language's distinction between on, off and over, sometimes seemed insufficient to critics who multiplied the categories to talk about sound, sometimes at the risk of obscuring discussion. The issue of taxonomy has been further complicated for French critics who have to deal with an imprecise translation of voice-over into voix-off. Nonetheless, the solution retained by most is to keep the traditional triad while insisting on the porosity of each category. Yet, it is important to keep in mind that in the area of film sound studies, the preference for certain terms may be linked to particular approaches. As film sound studies developed, they followed the theoretical path trodden by film studies in general. Thus, the psychoanalytic approach was adopted by several critics with even more enthusiasm when they chose to focus on the voice. Feminist scholars, who in the aftermath of Mulvey were concerned with issues of fetishism in film, saw in the female voice in cinema a topic that would demonstrate the patriarchal nature of the cinematic apparatus. Their contributions to the field remain landmarks for anyone studying the voice in audiovisual media. Despite the surge of interest for film sound that went hand in hand with such approaches, they were criticized for essentializing cinema through their lack of historical perspective and by not taking into account the variety of audience members.

With the coming of age of film sound studies, new perspectives have emerged. Scholars felt the need to combine different methodologies to comprehend the various facets of films as events. History, aesthetics, narratology, semiology, pragmatics and cognitive sciences are some of the approaches theoreticians have associated to take into account the particular contexts that influence the production and reception of film sound. They have also led to the analysis of the specificity of television sound. Such approaches have developed tools that can be applied to other audiovisual media, where the power of the voice is not to be underestimated. ${ }^{84}$ 


\section{BIBLIOGRAPHY}

Altman, Rick, ed. Cinema/Sound. vol. 60, Yale French Studies. New Haven: Yale University Press, 1980.

Altman, Rick. “Introduction.” Yale French Studies no. 60 (1980).

Altman, Rick. "Introduction: Four and a Half Film Fallacies." In Sound Theory, Sound Practice, edited by Rick Altman, 35-45. New York; London: Routledge, 1992.

Altman, Rick.“The Material Heterogeneity of Recorded Sound.” In Sound Theory, Sound Practice, edited by Rick Altman, 15-31. New York; London: Routledge, 1992.

Altman, Rick. Silent Film Sound. New York: Columbia University Press, 2004.

Altman, Rick, ed. Sound Theory, Sound Practice. New York; London: Routledge, 1992.

Arnheim, Rudolf. “A New Laocoön: Artistic Composites and the Talking Film.” In Film Sound: Theory and Practice, edited by Elisabeth Weis and John Belton, 112-15. New York: Columbia University Press, 1985.

Avron, Dominique. "Remarques sur le travail du son dans la production cinématographique standardisée." In Cinéma: théorie, lectures, edited by Dominique Noguez, 207-218. Paris: Klincksieck, 1978.

Bailblé, Claude. “Programmation de l'écoute (1)." Les Cahiers du cinéma no. 292, (1978): 54-59.

Bailblé, Claude. “Programmation de l'écoute (2)." Les Cahiers du cinéma no.293, (1978): 5-12.

Bailblé, Claude. “Programmation de l'écoute (3)." Les Cahiers du cinéma no. 297 (1979): 45-54.

Bailblé, Claude. “Programmation de l'écoute (4)." Les Cahiers du cinéma no. 299, (1979): 17-27.

Baudry, Jean-Louis. “Le Dispositif: approches métapsychologiques de l'impression de réalité." Communications no. 23 (1975): 56-72.

Beck, Jay and Tony Grajeda, eds. Lowering the Boom: Criticial Studies in Film Sound. Urbana and Chicago: University of Illinois Press, 2009.

Boillat, Alain. Du bonimenteur à la voix-over: voix-attraction et voix-narration au cinéma. Lausanne: Editions Antipodes, 2007.

Bonitzer, Pascal. Le Regard et la voix. Paris: 10: 18, 1976.

Châteauvert, Jean. Des mots à l'image: la voix over au cinéma. Québec; Paris: Nuit blanche éditeur; Méridiens Klincksieck, 1996.

Chevassu, François. “Le cinéma est sonore.” La Revue du cinéma/Image et son, no. 215 (1968): 10-40.

Chion, Michel. "100 concepts pour penser et décrire le cinéma sonore." <http:// www.michelchion.com/v1/index.php?option=com_content\&task=view\&id=45\&Itemid=60>, accessed 06/07/2013.

Chion, Michel. L'Audio-vision: son et image au cinéma. 2nd ed. Paris: Armand Colin, 1997.

Chion, Michel. La Voix au cinéma. Paris: Cahiers du Cinéma, Éditions de l’Étoile, 1982.

Chion, Michel. Le Son au cinéma. Nouvelle édition revue et corrigée ed. Paris: Cahiers du cinéma, 1992. 
Clair, René. “The Art of Sound." In Film Sound: Theory and Practice, edited by Elisabeth Weis and John Belton, 92-95. New York: Columbia University Press, 1985.

Doane, Mary Ann. "Ideology and the Practice of Sound Editing and Mixing." In Film Sound: Theory and Practice, edited by Elisabeth Weis and John Belton, 54-62. New York: Columbia University Press, 1985.

Doane, Mary Ann. The Desire to Desire: The Woman's Film of the 1940s. Bloomington: Indiana University Press, 1987.

Doane, Mary Ann. "The Voice in the Cinema: The Articulation of Body and Space." Yale French Studies no. 60 (1980): 33-50.

Eisenstein, Sergei, Vsevolod Pudovkin, and Grigori Alexandrov. "A Statement.” In Film Sound: Theory and Practice, edited by Elisabeth Weis and John Belton, 83-85. New York: Columbia University Press, 1985.

Gorbman, Claudia. "Bibliography on Sound in Film." Yale French Studies 60, (1980): 269-86. Harper, Graeme, Ruth Doughty and Jochen Eisentraut, eds. Sound and Music in Film and Visual Media: An Overview. New York: Continuum, 2009.

Jost, François. "Un Continent perdu: le son à la télévision.” In Le Son en perspective: nouvelles recherches/New Perspectives in Sound Studies, edited by Dominique Nasta and Didier Huvelle. Bruxelles: P.I.E. - Peter Lang, 2004.

Jost, François. De quoi les séries américaines sont-elles le symptôme ? Paris: CNRS Editions, 2011. Jullier, Laurent. "Être devant/Être dedans. Son et parole à la télévision d'un point de vue cognitiviste." In Téléparoles, edited by Guillaume Soulez, 8. Séminaire INA/Université de Metz, 2000.

Jullier, Laurent. L'Analyse de séquences. Paris: Armand Colin, 2011.

Jullier, Laurent. Les Sons au cinéma et à la télévision: précis d'analyse de la bande-son. Paris: Armand Colin, 1995.

Kozloff, Sarah. Invisible Storytellers: Voice-Over Narration in American Fiction Film. Berkeley: University of California Press, 1988.

Kracauer, Siegfried. Theory of Film: The Redemption of Physical Reality. Princeton, N.J.: Princeton University Press, 1997.

Lawrence, Amy. Echo and Narcissus: Women's Voices in Classical Hollywood Cinema. Berkeley and Los Angeles: University of California Press, 1991.

Mulvey, Laura. "Visual Pleasure and Narrative Cinema." Screen 16, no. 3 (1975): 6-18.

Odin, Roger. “Approche de la relation images-sons en termes de communication", L'analyse sémiologique des films, PhD dissertation, EHESS, Paris: 1982: vol. 1, 162-233.

Odin, Roger. De la fiction. Bruxelles: De Boeck, 2000.

Percheron, Daniel, and Marcia Butzel. "Sound in Cinema and its Relationship to Image and Diegesis." Yale French Studies no. 60 (1980): 16-23.

Restivo, Angelo. “Recent Approaches to Psychoanalytic Sound Theory.” Iris 27, (1999): 135-41.

Rosolato, Guy. La Relation d'Inconnu. Paris: Gallimard, 1978.

Schaeffer, Pierre. “L'Élément non visuel au cinéma (1): analyse de la 'bande-son'." La Revue du Cinéma no. 1 (1946): 45-48. 
Schaeffer, Pierre. "L'Élément non visuel au cinéma (2): conception de la musique." La Revue du Cinéma no. 2 (1946): 62-65.

Schaeffer, Pierre. "L'Élément non visuel au cinéma (3): psychologie du rapport vision-audition." La Revue du Cinéma no. 3 (1946): 51-54.

Sergi, Gianluca. The Dolby Era: Film sound in contemporary Hollywood. Manchester and New York: Manchester University Press, 2004.

Shingler, Martin. "Fasten Your Seatbelts and Prick Up Your Ears: The Dramatic Human Voice in Film." Scope 5 (2006) <http://www.scope.nottingham.ac.uk/article.php?issue=5\&id=128> accessed 05/08/2013.

Silverman, Kaja. “A Voice to Match: The Female Voice in Classic Cinema." Iris 3, no. 1 (1985): 57-69.

Silverman, Kaja. "Dis-Embodying the Female Voice." In Re-Vision: Essays in Feminist Film Criticism, edited by Mary Ann Doane, Patricia Mellencamp and Linda Williams, 131-49. Frederick, Md: University Publications of America, in association with the American Film Institute, 1984.

Silverman, Kaja. The Acoustic Mirror: The Female Voice in Psychoanalysis and Cinema. Bloomington: Indiana University Press, 1988.

Sjogren, Britta. Into the Vortex-Female Voice and Paradox in Film. Urbana and Chicago: University of Illinois Press, 2006.

Spottiswoode, Raymond. A Grammar of the Film: An Analysis of Film Technique: University of California Press, 1950.

Vale, Eugene. The Technique of Screen and Television Writing. Englewood Cliffs, NJ: Prentice Hall, 1982.

Vasse, Denis. L'Ombilic et la voix: Deux enfants en analyse. Paris: Éditions du Seuil, 1974.

Weis, Elisabeth, and John Belton, eds. Film Sound: Theory and Practice. New York: Columbia University Press, 1985.

\section{NOTES}

1. On this topic, see Rick Altman, Silent Film Sound (New York: Columbia University Press, 2004).

2. For an overview about voice in films not restricted to the voice over and with an emphasis on the physical aspect of sound, see Martin Shingler, "Fasten Your Seatbelts and Prick Up Your Ears: The Dramatic Human Voice in Film," Scope 5 (2006).

3. In sound studies, the two most developed areas of research concern film music and the transition from silent to sound film. For a bibliography about these topics see Claudia Gorbman, "Bibliography on Sound in Film," Yale French Studies 60 (1980).

4. Extracts from many of these early writings on film sound can be found in Elisabeth Weis and John Belton, eds, Film Sound: Theory and Practice (New York: Columbia University Press, 1985).

5. René Clair, "The Art of Sound," in Elisabeth Weis and John Belton, Film Sound: Theory and Practice.

6. Sergei Eisenstein, Vsevolod Pudovkin, and Grigori Alexandrov, "A Statement," in Weis and Belton, Film Sound: Theory and Practice.

7. Rudolf Arnheim, "A New Laocoön: Artistic Composites and the Talking Film," in Weis and Belton, Film Sound: Theory and Practice. 
8. Rick Altman, "Introduction: Four and a Half Film Fallacies," in Rick Altman, ed, Sound Theory, Sound Practice (New York; London: Routledge, 1992), 14.

9. Siegfried Kracauer, Theory of Film: The Redemption of Physical Reality (Princeton, N.J.: Princeton University Press, 1997), 103.

10. Jean-Louis Baudry, "Le dispositif: approches métapsychologiques de l'impression de réalité," Communications, no. 23 (1975): 61. The original reads: "en complétant la séance de projection par l'audition, en montrant en quelque sorte la nécessité de toucher le plus grand nombre de sens possibles, en tout cas les deux principaux, il paraît bien répondre à la nécessité de redoubler la réalité de la manière la plus exacte possible, de rendre son artifice autant qu'il se peut ressemblant."

11. Raymond Spottiswoode, A Grammar of the Film: An Analysis of Film Technique (Berkeley: University of California Press, 1950), 48-49.

12. Pierre Schaeffer, "L’Elément non visuel au cinéma (1): analyse de la "bande-son"," La Revue du Cinéma, no. 1 (1946); "L’Elément non visuel au cinéma (2): conception de la musique," La Revue du Cinéma, no. 2 (1946); "L’Elément non visuel au cinéma (3): psychologie du rapport visionaudition," La Revue du Cinéma, no. 3 (1946).

13. On industrial production of film sound see Dominique Avron, "Remarques sur le travail du son dans la production cinématographique standardisée," in Dominique Noguez, ed, Cinéma: théorie, lectures (Paris: Klincksieck, 1978).

14. On a side note, Schaeffer nevertheless proved quite forward-looking in his calls for film scholars and psychologists to work on sensations.

15. On this topic see Gianluca Sergi, The Dolby Era: Film Sound in Contemporary Hollywood (Manchester and New York: Manchester University Press, 2004).

16. Some pioneers defended the importance of film sound earlier, thus foreshadowing the trend of the following decades. See for instance François Chevassu, "Le cinéma est sonore", La Revue du cinéma/Image et son, no. 215 (1968).

17. Claude Bailblé, "Programmation de l'écoute (1)," Les Cahiers du cinéma no. 292 (1978); "Programmation de l'écoute (2)," Les Cahiers du cinéma no. 293 (1978); "Programmation de l'écoute (3)," Les Cahiers du cinéma no. 297 (1979); "Programmation de l'écoute (4)," Les Cahiers du cinéma no. 299, (1979).

18. Rick Altman, ed, Cinema/Sound, vol.60, Yale French Studies (New Haven: Yale University Press, 1980).

19. Michel Chion, L'Audio-vision: son et image au cinéma, 2nd ed. (Paris: Armand Colin, 1997).

20. Michel Chion, "100 concepts pour penser et décrire le cinéma sonore," <http:// www.michelchion.com/v1/index.php?option=com_content\&task=view\&id=45\&Itemid=60>, accessed 06/07/2013.

21. Altman, Sound Theory, Sound Practice.

22. Edited by Elisabeth Weis and John Belton in 1985, Film Sound: Theory and Practice is the other main reader on the topic. It brings together various generations of critics and therefore shows the evolution of sound theory over fifty years. It aims at redressing "two imbalances, one aesthetic, the other historical" in the study of film sound (Weis and Belton, ix). To do so, it develops the study of sound production.

23. Altman, Sound Theory, Sound Practice, 1.

24. Jay Beck and Tony Grajeda, eds, Lowering the Boom: Critical Studies in Film Sound (Urbana and Chicago: University of Illinois Press, 2009), 4.

25. Still today, screenwriting manuals recommend avoiding the voiceover since "One picture is worth a thousand words." Eugene Vale, The Technique of Screen and Television Writing. (Englewood Cliffs, NJ: Prentice Hall, 1982) 
26. Most English-speaking researchers choose the term voice-over as a generic term. In French, the traditional expression "voix off" tends to be replaced by "voix over," "off" being reserved for a voice whose source is in the diegesis but outside the frame.

27. Daniel Percheron and Marcia Butzel, "Sound in Cinema and its Relationship to Image and Diegesis," Yale French Studies, no. 60 (1980): 16.

28. Percheron and Butzel, "Sound in Cinema," 20.

29. Percheron and Butzel, "Sound in Cinema," 23.

30. Sarah Kozloff, Invisible Storytellers: Voice-Over Narration in American Fiction Film (Berkeley: University of California Press, 1988).

31. Kozloff, Invisible Storytellers, 45.

32. Michel Chion, La Voix au cinéma (Paris: Cahiers du Cinéma, Éditions de l'Étoile, 1982).

33. Chion's term of the "acousmaton" comes from the word "acousmatique," which was revived by Pierre Schaeffer in the 1950s. Here it is carefully defined and has been taken up by various critics.

34. Michel Chion, "100 concepts pour penser et décrire le cinéma sonore," <http:// www.michelchion.com/v1/index.php?option=com_content\&task=view\&id=45\&Itemid=60>, accessed 06/07/2013.

35. In a less systematic analysis on voice in films, Pascal Bonitzer distinguishes between two types of voice-off: the "off" voice, the voice that is outside the frame, and the voice that cannot communicate with what is shown on screen. The filmmaker and theoretician associates a specific power to the latter, that of controlling the image from a transcendent place. Pascal Bonitzer, $L e$ Regard et la voix (Paris: 10-18, 1976), 31-33

36. Mary Ann Doane, "The Voice in the Cinema: The Articulation of Body and Space," Yale French Studies, no. 60 (1980).

37. Kaja Silverman, "Dis-Embodying the Female Voice," in Mary Ann Doane, Patricia Mellencamp, and Linda Williams, eds, Re-Vision: Essays in Feminist Film Criticism (Frederick, Md: University Publications of America, in association with the American Film Institute, 1984).

38. Kaja Silverman, The Acoustic Mirror: The Female Voice in Psychoanalysis and Cinema (Bloomington: Indiana University Press, 1988).

39. Chion, "100 Concepts pour penser et décrire le cinéma sonore."

40. Michel Chion, Le Son au cinéma, nouvelle édition revue et corrigée (Paris: Cahiers du cinéma, 1992).

41. Alain Boillat, Du bonimenteur à la voix-over: voix-attraction et voix-narration au cinéma (Lausanne: Editions Antipodes, 2007).

42. Britta Sjogren, Into the Vortex-Female Voice and Paradox in Film (Urbana and Chicago: University of Illinois Press, 2006).

43. Sjogren, Into the Vortex, 8.

44. Sjogren, Into the Vortex, 9.

45. Chion, Le Son au cinéma, 34.

46. Laurent Jullier, L'Analyse de séquences (Paris: Armand Colin, 2011), 119-25.

47. For additional references on psychoanalytic approaches to film sound in the 1990s see Angelo Restivo, "Recent Approaches to Psychoanalytic Sound Theory," Iris 27 (1999).

48. Bailblé, "Programmation de l'écoute (1)."

49. Chion, La Voix au cinéma.

50. Restivo, "Recent Approaches to Psychoanalytic Sound Theory," 136.

51. Guy Rosolato, La Relation d'Inconnu (Paris: Gallimard, 1978).

52. Denis Vasse, L'Ombilic et la voix: Deux enfants en analyse (Paris: Editions du Seuil, 1974).

53. Chion, La Voix au cinéma, 78. The original reads: "Le cri de l'homme délimite un territoire, le cri de la femme renvoie à l'illimité, il avale tout en lui-même, il est centripète et fascinant, alors 
que le cri de l'homme est centrifuge et structurant. Le point de cri est comme le point de butée des mots, la sortie de l'être."

54. Restivo, "Recent Approaches to Psychoanalytic Sound Theory," 137.

55. Laura Mulvey, "Visual Pleasure and Narrative Cinema," Screen 16, no. 3 (1975).

56. Doane, "The Voice in the Cinema."

Mary Ann Doane, "Ideology and the Practice of Sound Editing and Mixing," in Elisabeth Weis and John Belto, eds, Film Sound: Theory and Practice (New York: Columbia University Press, 1985).

57. Mary Ann Doane, The Desire to Desire: The Woman's Film of the 1940s (Bloomington: Indiana University Press, 1987).

58. Doane, The Desire to Desire, 21.

59. Doane, The Desire to Desire, 8.

60. Silverman, The Acoustic Mirror.

61. Silverman, The Acoustic Mirror, ix.

62. Silverman, The Acoustic Mirror, ix.

63. Kaja Silverman, "A Voice to Match: The Female Voice in Classic Cinema," Iris 3, no. 1 (1985): 60.

64. For a thorough criticism of Silverman's Acoustic Mirror, see Sjogren, Into the Vortex, who claims that Silverman remains trapped by a visual bias that sees "the image as primary and the voice as, in a sense, its prisoner" (14).

65. Altman, "Introduction."

66. Altman, "Introduction," 39.

67. Altman, "Introduction," 39.

68. Sjogren, Into the Vortex, 3-4.

69. Sjogren, Into the Vortex, 61.

70. Amy Lawrence, Echo and Narcissus: Women's Voices in Classical Hollywood Cinema (Berkeley and Los Angeles: University of California Press, 1991).

71. Lawrence, Echo and Narcissus, 29.

72. Lawrence, Echo and Narcissus, 32.

73. Rick Altman, "The Material Heterogeneity of Recorded Sound," in Altman, Sound Theory, Sound Practice, 15.

74. Altman, Sound Theory, Sound Practice, 7.

75. Altman, Sound Theory, Sound Practice, 9.

76. The semio-pragmatic approach is defined by Roger Odin as a heuristic model that assumes a text is produced in a two-fold process: in the space of production and in the space of reception. This approach was outlined in Odin's PhD dissertation published in 1982 "Approche de la relation images-sons en termes de communication", L'Analyse sémiologique des films. PhD dissertation, EHESS. It is explained in further details in De la fiction (Bruxelles: De Boeck, 2000).

77. Jean Châteauvert, Des mots à l'image: la voix over au cinéma (Québec; Paris: Nuit blanche éditeur; Méridiens Klincksieck, 1996).

78. Boillat, Du bonimenteur à la voix-over.

79. Boillat, Du bonimenteur à la voix-over, 498. The original reads: "Ainsi les régimes vocaux identifiés dans ce travail permettent à mon sens de distinguer les principaux domaines d'application de la voix-over, ainsi que des procédés plus spécifiques à l'intérieur de ceux-ci: le doublage, la post-synchronisation de films d'animation et les boîtes vocales relèvent de la voixaction, l'animation radio et la publicité de la voix-attraction, les films industriels, CD-ROM et jeux vidéo de la voix-narration, alors que d'autres productions se situent entre ces deux dernières (les bandes-annonces, les sites Web, etc.)."

80. François Jost, "Un continent perdu: le son à la télévision," in Dominique Nasta and Didier Huvelle, ed., Le Son en perspective: nouvelles recherches/New Perspectives in Sound Studies (Bruxelles: P.I.E. - Peter Lang, 2004). 
81. François Jost, De quoi les séries américaines sont-elles le symptôme? (Paris: CNRS Editions, 2011), 37.

82. Laurent Jullier, Les Sons au cinéma et à la télévision: précis d'analyse de la bande-son (Paris: Armand Colin, 1995), 111.

83. Laurent Jullier, "Etre devant/Etre dedans. Son et parole à la télévision d'un point de vue cognitiviste," in Guillaume Soulez, ed, Téléparoles (Séminaire INA/Université de Metz, 2000).

84. See Graeme Harper, Ruth Doughty and Jochen Eisentraut, eds, Sound and Music in Film and Visual Media: An Overview (New York: Continuum, 2009). This impressive volume of over 800 pages includes almost fifty essays, whose diversity testifies to the dynamism of the field. These notably include a contribution on music in videogames, another on the semiotics of the voice, one on the figure of the sound designer, several essays on sound in television (fiction, reality-TV, news...) as well as many more on the various uses of sound in cinema.

\section{ABSTRACTS}

After a survey of the major critical trends since the generalization of synchronized film sound, this bibliographical essay sets out to delineate the way film sound studies have developed around issues of taxonomy, meaning, and reception. Focusing on the treatment of the disembodied voice by various theorists, three trends can be identified: borrowing from semiology and narratology, an essentially descriptive approach first emerges that creates a new vocabulary to talk about sound and analyze the links between sound and image. A second approach emphasizes the possible meanings of the disembodied voice, a trend heavily influenced by Lacanian theories and their later adaptations by feminist film theorists. Finally, some researchers have opted for semiopragmatic or cognitive approaches that take into account the experience of audiences. These different approaches underline the way film sound has evolved as an object of study, to be considered as a complex and flexible phenomenon. They also have developed tools that can be applied to other audiovisual media in which the role of sound and the voice should not be underestimated.

\section{INDEX}

Keywords: film sound, voice-over, audiovisual, reception, television

\section{AUTHOR}

\section{ANAÏS LE FÈVRE-BERTHELOT}

Anaïs Le Fèvre-Berthelot is a doctoral student at the Paris 3 - Sorbonne Nouvelle University. She is currently working on women's voices in contemporary American TV series. 